\title{
Characterization of Active Faulting Beneath the Strait of Georgia, British Columbia
}

\author{
by John F. Cassidy, Garry C. Rogers, and Felix Waldhauser
}

\begin{abstract}
Southwestern British Columbia and northwestern Washington State are subject to megathrust earthquakes, deep intraslab events, and earthquakes in the continental crust. Of the three types of earthquakes, the most poorly understood are the crustal events. Despite a high level of seismicity, there is no obvious correlation between the historical crustal earthquakes and the mapped surface faults of the region. On 24 June 1997, a $M_{\mathrm{L}}=4.6$ earthquake occurred 3-4 km beneath the Strait of Georgia, $30 \mathrm{~km}$ to the west of Vancouver, British Columbia. This well-recorded earthquake was preceded by 11 days by a felt foreshock $\left(M_{\mathrm{L}}=3.4\right)$ and was followed by numerous small aftershocks. This earthquake sequence occurred in one of the few regions of persistent shallow seismic activity in southwestern British Columbia, thus providing an ideal opportunity to attempt to characterize an active near-surface fault. We have computed focal mechanisms and utilized a waveform cross-correlation and joint hypocentral determination routine to obtain accurate relative hypocenters of the mainshock, foreshock, and 53 small aftershocks in an attempt to image the active fault and the extent of rupture associated with this earthquake sequence. Both $P$ nodal and CMT focal mechanisms show thrust faulting for the mainshock and the foreshock. The relocated hypocenters delineate a north-dipping plane at 2-4 km depth, dipping at $53^{\circ}$, in good agreement with the focal mechanism nodal plane dipping to the north at $47^{\circ}$. The rupture area is estimated to be a $1.3-\mathrm{km}$-diameter circular area, comparable to that estimated using a Brune rupture model with the estimated seismic moment of $3.17 \times 10^{15} \mathrm{~N}$ m and the stress drop of 45 bars. The temporal sequence indicates a downdip migration of the seismicity along the fault plane. The results of this study provide the first unambiguous evidence for the orientation and sense of motion for active faulting in the Georgia Strait area of British Columbia.
\end{abstract}

\section{Introduction}

Southwestern British Columbia and northwestern Washington State overlie the Cascadia subduction zone. There are three sources of seismic activity in this region: (1) rare ( $\sim 500$ year return period), but extremely large $(M$ $\sim 9$ ) megathrust earthquakes, which occur on the boundary between the subducting Juan de Fuca plate and the overlying North American plate; (2) intraslab earthquakes, which occur within the subducting oceanic plate; and (3) crustal seismicity in the North American plate. Of these three sources, the crustal earthquakes are the least understood. Most occur at midcrustal depths, and typically there is no correlation with surface faults. Understanding the nature of the crustal earthquakes is of great importance, as the crustal seismicity is concentrated in the populated regions of the Puget Lowlands-Georgia Basin (Rogers, 1998).

Recently, major east-west-trending faults have been discovered beneath Puget Sound. One of the most prominent, the Seattle fault, shows clear evidence (Bucknam et al., 1992) for a large $(M>7)$ shallow crustal event ca. A.D. 900 and may be associated with moderate $(M \leq 5)$ historical seismicity (Dewberry and Crosson, 1996; Weaver et al., 1999). The identification of this active fault in the Puget Sound has made a significant impact on the earthquake hazard estimates for the Seattle region (Frankel et al., 1996). Similarly, the identification of active, or potentially active structures near the urban areas of southwestern British Columbia is an important issue to address.

On 24 June 1997 a magnitude $\left(M_{\mathrm{L}}\right) 4.6$ earthquake occurred beneath the Strait of Georgia, $30 \mathrm{~km}$ to the west of Vancouver (Fig. 1). This earthquake was the mainshock of an earthquake sequence that began with a $M_{\mathrm{L}}=3.4$ event on 13 June 1997 and continued for several months with numerous, small $\left(M_{\mathrm{L}}<2\right)$ aftershocks. Occurring in a region of concentrated shallow ( $<6 \mathrm{~km}$ depth) seismicity, this 
Felt Reports - June 241997 Earthquake

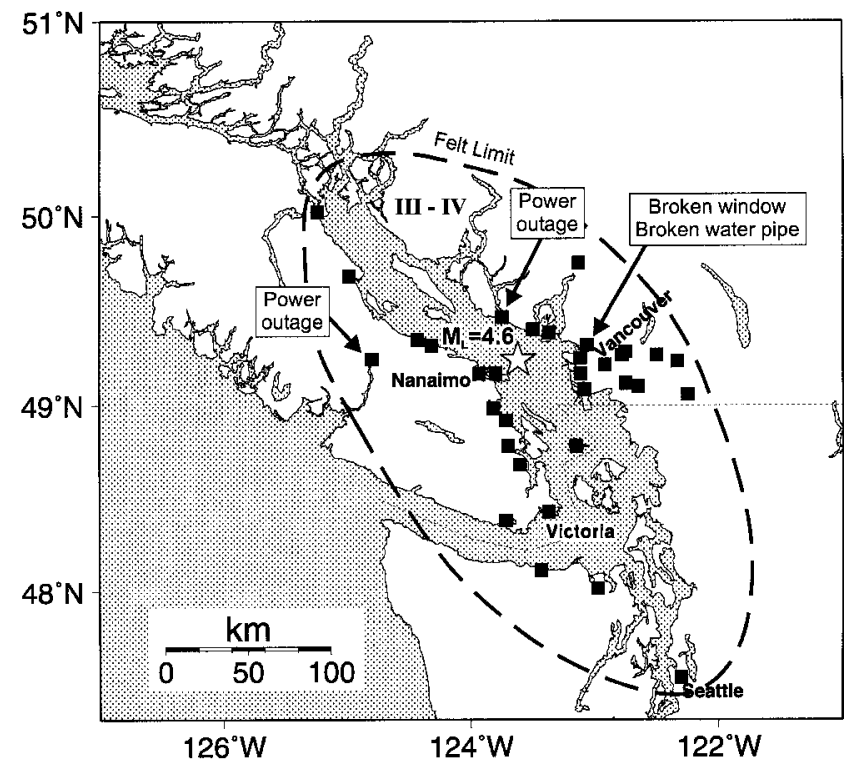

Figure 1. Location map showing the epicenter (star) of the 24 June $1997 M_{\mathrm{L}}=4.6$ Georgia Strait earthquake, communities where it was felt (filled squares), and the felt limit (dotted line). Most reports indicated a Modified Mercalli Intensity of III-IV. There were two reports of minor damage in greater Vancouver, and two power outages triggered by this earthquake.

earthquake sequence provides an excellent opportunity to define the orientation and sense of motion on an active fault near the urban centers of southwestern British Columbia.

In this article, we (1) compute focal mechanisms for the mainshock, foreshock, and largest aftershocks of the 24 June 1997 earthquake; and (2) utilize waveform cross-correlation and a joint hypocentral determination routine to obtain accurate relative hypocenters of the mainshock, foreshock, and 53 small aftershocks in order to image the fault associated with this shallow, crustal earthquake sequence.

The 24 June 1997 Earthquake Sequence

On 24 June 1997 at 14:40 UTC (07:40 a.m. local time) a moderate $\left(M_{\mathrm{L}}=4.6, M_{\mathrm{W}}=4.3\right)$ earthquake occurred 3$4 \mathrm{~km}$ beneath the Strait of Georgia, about $30 \mathrm{~km}$ from the urban core of Vancouver, and midway between Nanaimo on Vancouver Island, and Vancouver, on the British Columbia mainland (Fig. 1). This earthquake was felt over an area of about $60,000 \mathrm{~km}^{2}$, including southern Vancouver Island, the Sunshine coast, greater Vancouver, and as far east as Abbotsford and as far south as Seattle (Fig. 1). In most cases, the felt reports indicated a Modified Mercalli Intensity of III-IV. There were two reports of minor damage: broken glass in Vancouver and a broken water pipe in North Vancouver (Fig. 1). This earthquake was preceded by 11 days by a felt $M_{\mathrm{L}}=3.4$ foreshock and was followed by numerous small $\left(M_{\mathrm{L}}<1.7\right)$ aftershocks. The earthquake sequence was well recorded on stations of the Canadian National Seismograph Network in southwestern British Columbia, providing, to date, the best data set for source studies in the epicentral region.

\section{Overview of Previous Seismicity}

Shallow, crustal earthquakes pose a significant hazard to the populated areas of southwestern British Columbia (Rogers, 1998) and the United States Pacific Northwest. Crustal earthquakes of magnitude 7 or larger occurred in 1872 in northern Washington State, and in 1918 and 1946 on Vancouver Island (Fig. 2). Moderate crustal earthquakes occurred in northern Washington State in 1990 and 1996, and beneath the Strait of Georgia in 1975 and 1997. Each of these moderate earthquakes was shallow $(<5 \mathrm{~km})$ and followed by numerous aftershocks. Small, $(M<3)$ crustal earthquakes occur daily in this region. In Figure 2, the best located earthquakes (e.g., those recorded by modern seismograph networks) in the North American plate (focal depth less than about $35 \mathrm{~km}$ ) are compared to the location of the largest crustal events. Rogers (1998) notes that: (1) the small crustal earthquakes tend to be concentrated in the Strait of Georgia-Puget Sound lowland; (2) most are at depths of 15$25 \mathrm{~km}$; and (3) there is no obvious correlation between the small crustal earthquakes and the three largest historical crustal earthquakes in this area. Although this area is very active seismically, there is no distinctive alignment of epicenters to indicate active faults. Further, no evidence for active surface faulting has been found in southwestern British Columbia, to date. It is noteworthy that focal mechanisms for crustal earthquakes in southwestern British Columbia (e.g., Rogers, 1979; Mulder, 1995) and northwestern Washington State (e.g., Ma et al., 1991) typically have thrust mechanisms or strike slip mechanisms with nearly horizontal $P$ axes oriented N-S in Washington State and NNW-SSE in southwest British Columbia, indicating a margin-parallel compressive stress regime.

Considering only the shallowest of the crustal earthquakes (focal depth $<6 \mathrm{~km}$ ) recorded by dense seismograph networks in this area (1975-present), one finds that the location of the 24 June 1997 earthquake sequence has been a site of persistent shallow seismic activity beneath the Strait of Georgia (Fig. 3). In 1975, a shallow $M=4.9$ thrust earthquake (Rogers, 1979) with a long aftershock sequence occurred here and, since then, several small felt events have occurred. Given the concentration of shallow seismic activity, this is an ideal site at which to look for evidence of active surface faulting in the marine environment (e.g., disturbed sediments).

\section{Geological Setting and Recent Geophysical Studies}

The 1997 earthquake sequence occurred beneath the Strait of Georgia, which lies within the Georgia Basin (Fig. 4); a structural and sedimentary, Cretaceous to Cenozoic forearc basin that overlies the subducting Juan de Fuca plate. The Georgia Basin occupies a similar position to that of the 
North American Plate Seismicity 1980-1990

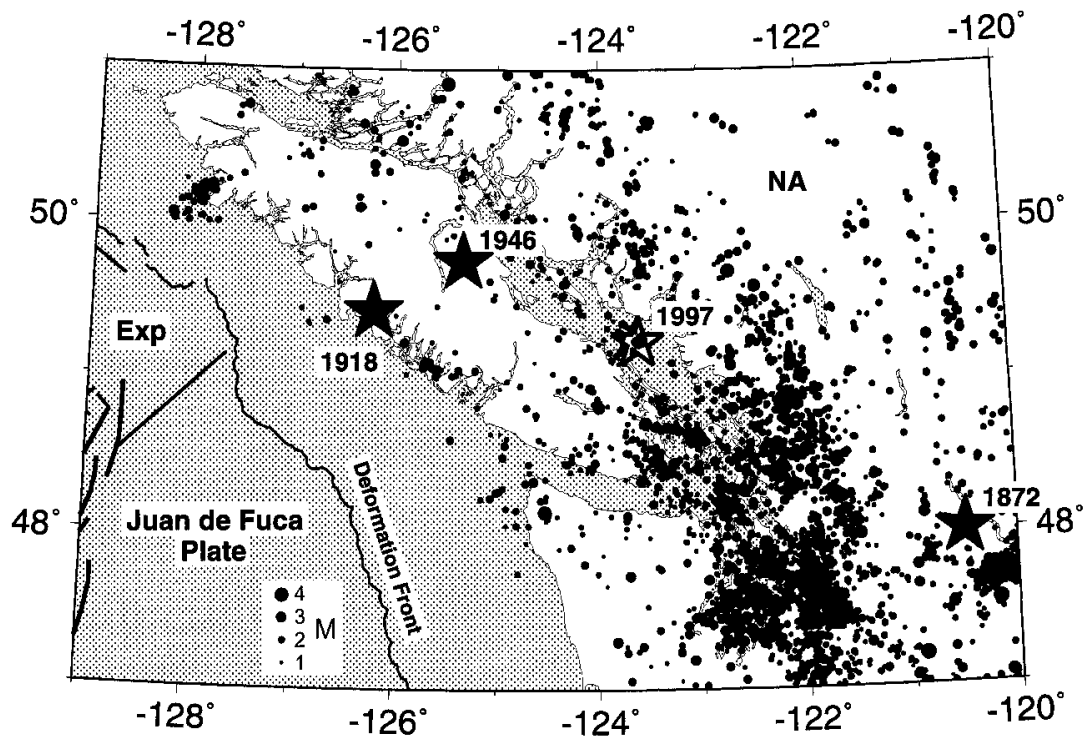

Figure 2. North American plate seismicity for the period 1980-1990 (dots), the locations of the largest crustal earthquakes $(M \geqq 7)$ in this region (solid stars), and the epicenter of the June 1997 earthquake (open star). The Juan de Fuca Plate, Explorer Plate (Exp) and North American Plate (NA) and the deformation front offshore are labelled. Earthquake data from the Geological Survey of Canada and University of Washington.

$M>2$ Shallow ( $Z<6 \mathrm{~km}$ ) Crustal Earthquakes 1975-1999

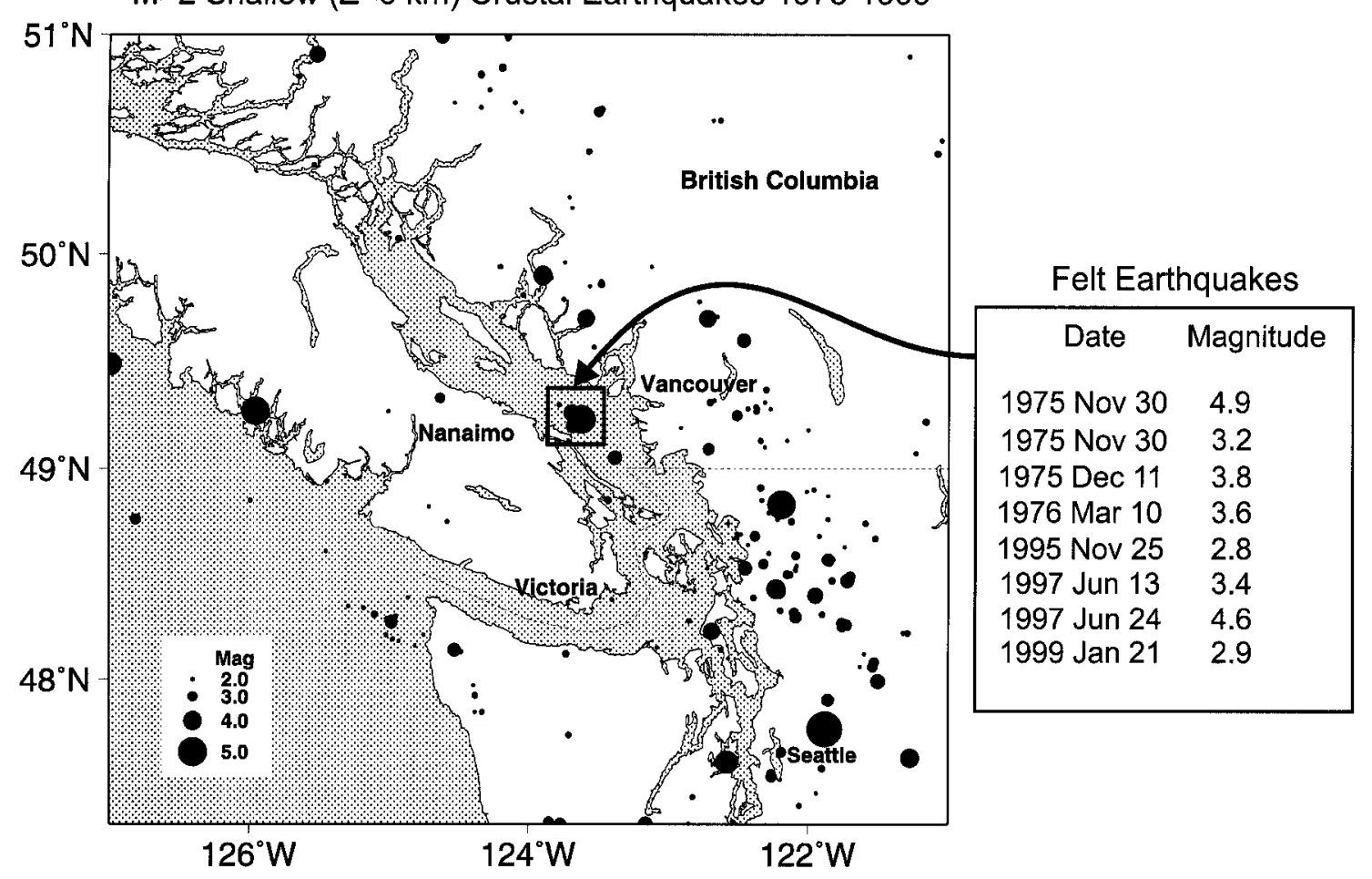

Figure 3. Location of all shallow (depth $<6 \mathrm{~km}$ ) $M_{\mathrm{L}}>2$ earthquakes in the North American Plate during the period 1975-1999. The location of the 24 June 1997 earthquake is one of recurring shallow seismicity.

Puget Sound lowland in Washington State. There, seismic images, gravity data, and magnetic data reveal a series of northwest to west trending faults and folds beneath Puget Sound (Fig. 4) that have been interpreted as representing a north moving "thin-skinned" thrust sheet (Pratt et al., 1997).
The most prominent of the faults identified in the Puget Lowland is the east-west trending, south-dipping Seattle Fault (Pratt et al., 1997; Johnson et al., 1999a). This fault was associated with a $M>7$ event ca. A.D. 900 (Bucknam et al., 1992), and may be seismically active today (Dewberry 
and Crosson, 1996; Weaver et al., 1999). In northern Puget Sound, the Devils Mountain Fault (Fig. 4) is a north-dipping, east-west-trending thrust fault that coincides with aeromagnetic and gravity anomalies (Johnson et al., 1999b).

In the vicinity of the 24 June 1997 earthquake sequence, the Wrangellia terrane forms the basement of the Georgia Basin (Monger, 1990; Zelt et al., 1993; Monger and Journeay, 1994). This is overlain by an approximately $2-\mathrm{km}$ thick sedimentary package comprising the marine Upper Cretaceous Nanaimo Group (primarily sandstone, conglomerate, and shale), the Eocene nonmarine sedimentary rocks of the Chuckanut Formation and Pleistocene glacial deposits. This package is capped by up to $400 \mathrm{~m}$ of unconsolidated Holocene sediments that represent Fraser River outwash (Mosher and Hamilton, 1998).

The overall structure of the Georgia Basin indicates moderate deformation along a series of mainly northwesttrending faults and folds (England and Bustin, 1998). Much of the Nanaimo group is characterized by shallow northeastto east-dipping beds (Mustard and Rouse, 1994), which locally may reverse their dip over northwest trending folds.

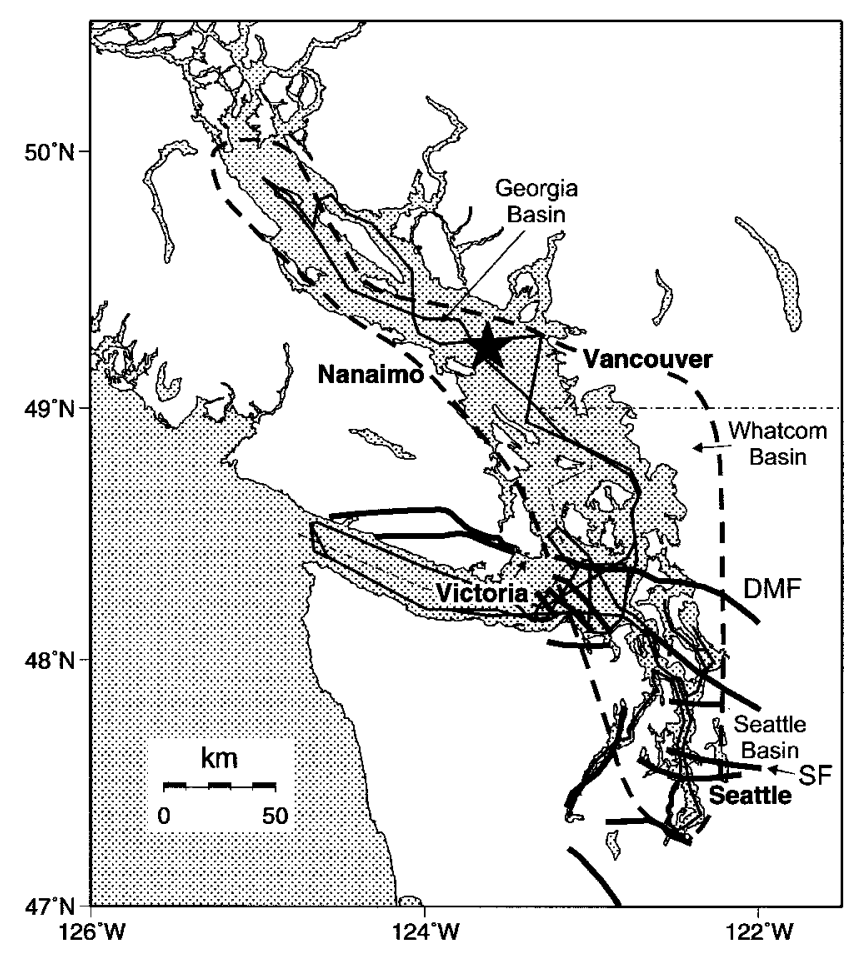

Figure 4. The Georgia Basin is one of a series of basins found in the Georgia Strait-Puget Sound lowlands (outlined by thick dashed line). In the Puget Sound region, a number of east-west- to southeastnorthwest-striking thrust faults (thick black lines) have been recently imaged, including the Devils Mountain Fault (DMF) and the seismically active Seattle Fault (SF). Seismic lines of the SHIPS experiment (thin lines) covers the region, including the epicentral area of the 24 June 1997 Georgia Strait earthquake (star).
However, there is considerable debate over the details of the structure of the Georgia Basin (Mustard and Rouse, 1994; England and Bustin, 1998). Although major faults have been proposed for the Strait of Georgia area (Muller, 1977), none have been found. Using seismic refraction and reflection data, White and Clowes (1984) found evidence for a small local fault beneath the Strait of Georgia (about $18 \mathrm{~km}$ to the southeast of the 24 June 1997 epicenter) but could not constrain the dip direction or dip angle of this feature.

The 1998 SHIPS experiment (Fisher et al., 1999) was designed, in part, to examine the crustal and detailed nearsurface structure beneath the Strait of Georgia in the vicinity of the 24 June 1997 earthquake (Fig. 4). Preliminary results of the multichannel seismic reflection study are discussed later in this article and are presented in Mosher et al. (2000).

\section{The Data Set}

The 24 June 1997 foreshock, mainshock, and aftershock sequence were well recorded on the short-period and broadband stations of the Canadian National Seismograph Network (CNSN) in southwestern British Columbia (Fig. 5). The sampling rate for these digital recordings are $100 \mathrm{~Hz}$ (shortperiod data), and $40 \mathrm{~Hz}$ (broadband data). The waveform data utilized in this study consist of recordings of 76 earthquakes: the 13 June $1997 M_{\mathrm{L}}=3.4$ earthquake and six small $\left(M_{\mathrm{L}}=0.3-0.7\right)$ aftershocks of this event, and the 24 June 1997 mainshock $\left(M_{\mathrm{L}}=4.6\right)$ and 68 aftershocks of $M_{\mathrm{L}}=$ 0.4-1.8 that occurred between 24 June 1997 and 19 March

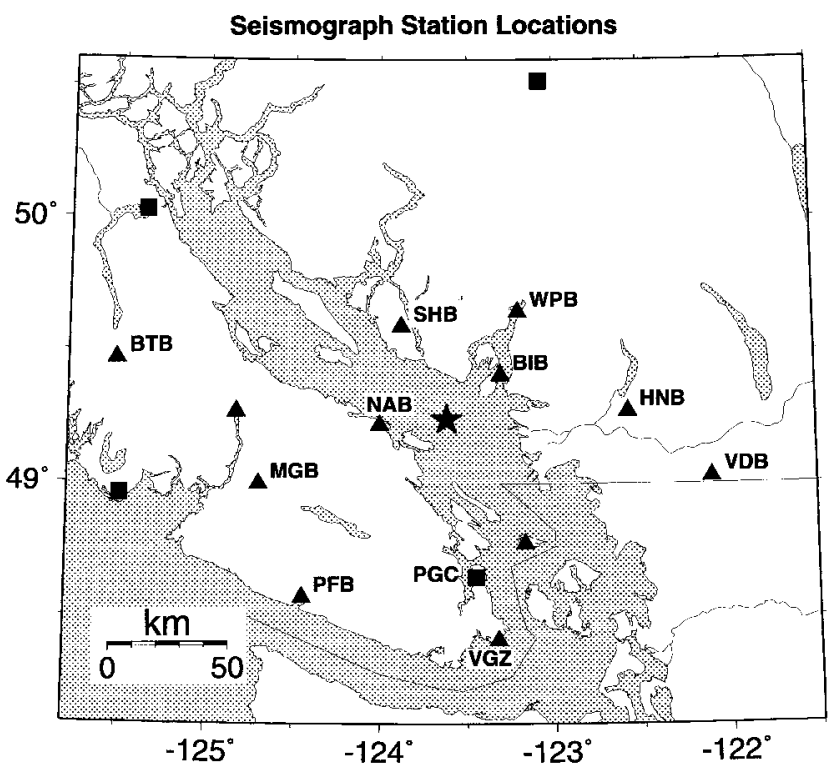

Figure 5. Digital seismograph stations operating in southwestern British Columbia at the time of the earthquake. Triangles are short-period vertical component instruments, and squares are three-component broadband seismographs. The star denotes the location of the 24 June $1997 M_{\mathrm{L}}=4.6$ earthquake. Labelled stations are those used in this study. 
1998 (34 of which occurred within one month of the mainshock). The closest stations are NAB (28 km west of the epicenter), and BIB (30 km to the northeast); the most distant station used for the earthquake relocation was BTB $(140 \mathrm{~km}$ to the west).

In addition, the 24 June 1997 mainshock triggered strong-motion instruments at 19 sites in southwestern British Columbia. For more information on the strong-motion data sets and their interpretation, see Cassidy et al. (1998) and Cassidy and Rogers (1999).

\section{Data Analysis}

\section{Focal Mechanisms}

Of the earthquakes, only the $M_{\mathrm{L}}=4.6$ mainshock and the $M_{\mathrm{L}}=3.4$ foreshock provided sufficient data for a wellconstrained $P$-nodal solution. For the mainshock, a total of 73 first motions were read from seismograms of the CNSN and the nearby Pacific Northwest Seismograph Network (PNSN). Of these, 10 were from three-component broadband waveforms, and 63 were from short-period vertical-component waveforms. Using the $P$-nodal analysis program $f p f i t$ (Reasenberg and Oppenheimer, 1985) we find a well constrained focal mechanism showing thrust faulting (Fig. 6) along either a north-dipping fault (strike $262^{\circ}$, dip $47^{\circ}$, slip $98^{\circ}$ ), or along a south-dipping fault (strike $71^{\circ}$, dip $44^{\circ}$, slip $82^{\circ}$ ). A centroid moment tensor solution for this earthquake, computed by Oregon State University (Malone et al., 1997), using regional broadband data from 12 stations, shows a very similar thrust solution on a north-dipping fault of strike $278^{\circ}$, dip $56^{\circ}$, slip $120^{\circ}$ (Fig. 6).

For the 13 June foreshock, a total of 34 first motions were read from seismograms of the CNSN and the PNSN. Of these, six were from three-component broadband waveforms, and 28 were from short-period vertical-component waveforms. Most of the first motions are identical to those of the mainshock; however, there are four clear polarity differences, requiring a slightly different focal mechanism. The fpfit top-scoring solution for the foreshock is a mixture of thrust and strike-slip faulting (Fig. 6) along either a northnorthwest-dipping fault (strike $236^{\circ}$, dip $42^{\circ}$, slip $123^{\circ}$ ), or along an east-dipping fault (strike $15^{\circ}$, dip $56^{\circ}$, slip $64^{\circ}$ ). This mechanism is not as well constrained as the mainshock, and solutions ranging from thrust (similar to the mainshock) to predominantly strike slip along an east-west-striking, northdipping fault (strike $266^{\circ}$, dip $72^{\circ}$, slip $156^{\circ}$ ) are permitted by the first motion data (Fig. 6). The centroid moment tensor solution for this earthquake (Malone et al., 1997), obtained using regional broadband data from nine stations, shows a predominantly thrust mechanism (strike $259^{\circ}$, dip $67^{\circ}$, slip $106^{\circ}$ ) that is rotated $19^{\circ}$ counterclockwise relative to the mainshock CMT solution (Fig. 6).

In summary, the mainshock shows thrust faulting (strike $262^{\circ}$, dip $47^{\circ}$, slip $98^{\circ}$ ) as determined from both the $P$-nodal solution and the CMT solution. It is very similar to the focal

\section{FOCAL MECHANISMS}
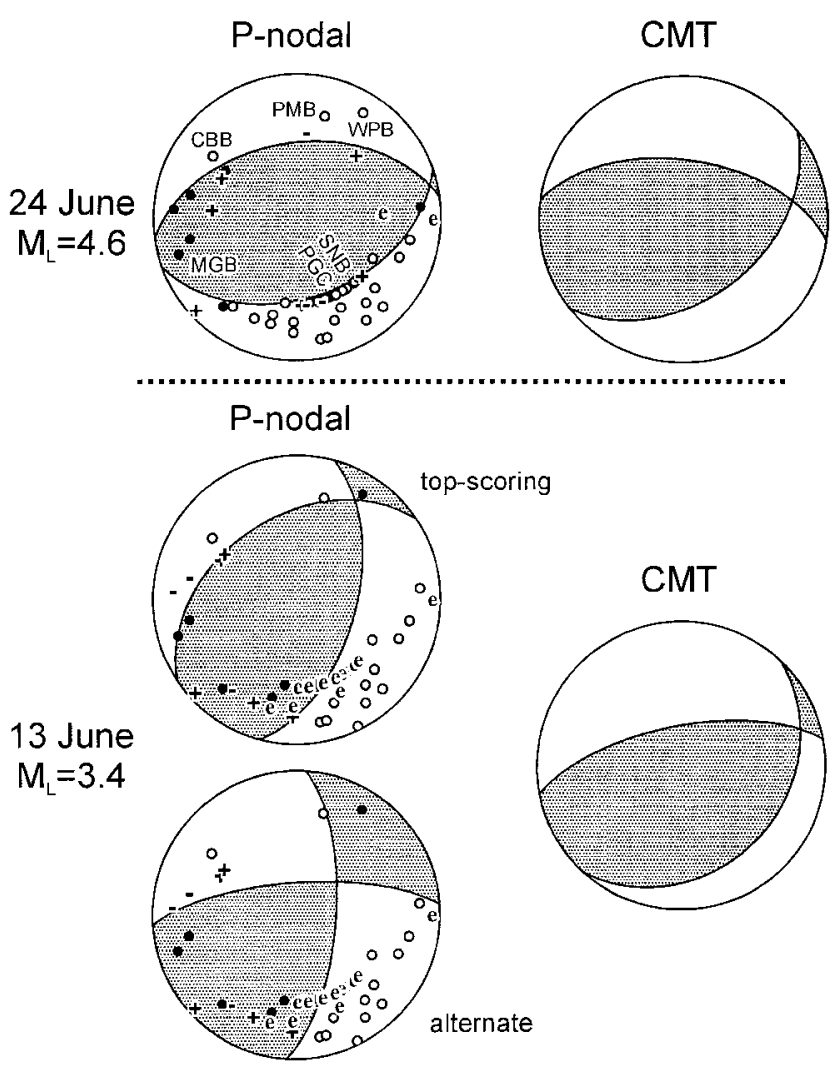

Figure 6. Focal mechanism solutions for the 24 June $1997 M_{\mathrm{L}}=4.6$ mainshock (top) and the $M_{\mathrm{L}}=$ 3.4 foreshock of 13 June 1997 (bottom). First motion data are shown on the $P$-nodal solutions; filled dots, impulsive compressions; open circles, impulsive dilatations; +, emergent compressions, - , emergent dilatations; e, emergent arrivals for which polarities could not be read. Lower hemisphere projections were used in all cases. Oregon State University moment tensor solutions (shown on the right for both earthquakes) utilized regional waveform modelling.

mechanism of a $M_{\mathrm{L}}=4.9$ earthquake in 1975 (Rogers, 1979) that occurred at the same location as the 1997 earthquake sequence. Our preferred mechanism for the foreshock is predominantly thrust (strike $236^{\circ}$, dip $42^{\circ}$, slip $123^{\circ}$ ) as suggested by both the $P$-nodal and CMT solutions. However, we cannot rule out a strike-slip mechanism for this event. The pressure axes for both earthquakes are near-horizontal and orientated NNW to NW ( $346^{\circ}$ for the mainshock, and $303^{\circ}$ for the foreshock), consistent with the overall orientation of $P$-axes for crustal earthquakes in southwest British Columbia (Mulder, 1995).

The other aftershocks considered in this study are all too small for a well-constrained $P$-nodal solution. We note, however, that the first motions that can be read for the five largest aftershocks $\left(M_{\mathrm{L}}=1.5-1.8\right)$ are consistent with the mainshock first motions; suggesting similar focal mechanisms for the largest aftershocks. 


\section{Earthquake Hypocenters}

Network Locations. The routine network locations of the earthquakes $\left(M_{\mathrm{L}}=0.3-4.6\right)$ considered in this study were obtained using $P$ and $S$-wave arrival times at stations of the CNSN in southwest British Columbia at distances of about 30-120 km (Figure 5). The locations were obtained using the program LocEq (Baldwin, 1993), which employs downhill simplex to minimize, in a least-squares sense, both the $P$-wave and $S$-wave travel-time residuals. Between 6 and 19 $P$ and $S$ phases (generally $8-12$ ) from 4 to 13 stations (typically 6-8) were utilized in these locations. The closest stations were at distances of about $30 \mathrm{~km}$, and therefore the focal depths are not well constrained. However, the range of focal depths $(0-5 \mathrm{~km})$ is reasonable, and it is likely that these earthquakes occurred within about $5 \mathrm{~km}$ of the surface.

The routine network locations of the 76 events that were considered in this study show scatter over a circular region about $3 \mathrm{~km}$ in diameter (Fig. 7). There is no obvious alignment of epicenters in the map view, nor is there an alignment of hypocenters in the cross-sectional views (Fig. 7). The routine location errors $(1 \sigma)$ average $\pm 2.8 \mathrm{~km}$ horizontally and $\pm 6.9 \mathrm{~km}$ vertically. Based on the routine network locations and their estimated errors, one cannot resolve any structure, or potential fault plane.

Relocation of Hypocenters Using Waveform CrossCorrelation. The similarity of the focal mechanisms of the foreshock/mainshock and the small volume in which the events occurred makes the earthquake cluster suitable for precise relative event location using waveform crosscorrelation. To relocate the hypocenters of the foreshock, mainshock, and aftershock sequence, we utilize the analysis package Xadjust (Dodge, 1996). This uses a waveform cross-correlation routine (VanDecar and Crosson, 1990) to obtain precise relative $P$-wave and $S$-wave arrival times with respect to a master event. The measurements are subsequently inverted using the program VELEST (Ellsworth, 1977; Roecker, 1981) to obtain hypocentral parameters, station corrections, and model adjustments. It is assumed that all of the unmodelled velocity structure can be absorbed into station corrections. For more details on the analysis method, see Dodge et al. (1995, 1996).

The $P$ - and $S$-wave train of the bandpass-filtered (2-8

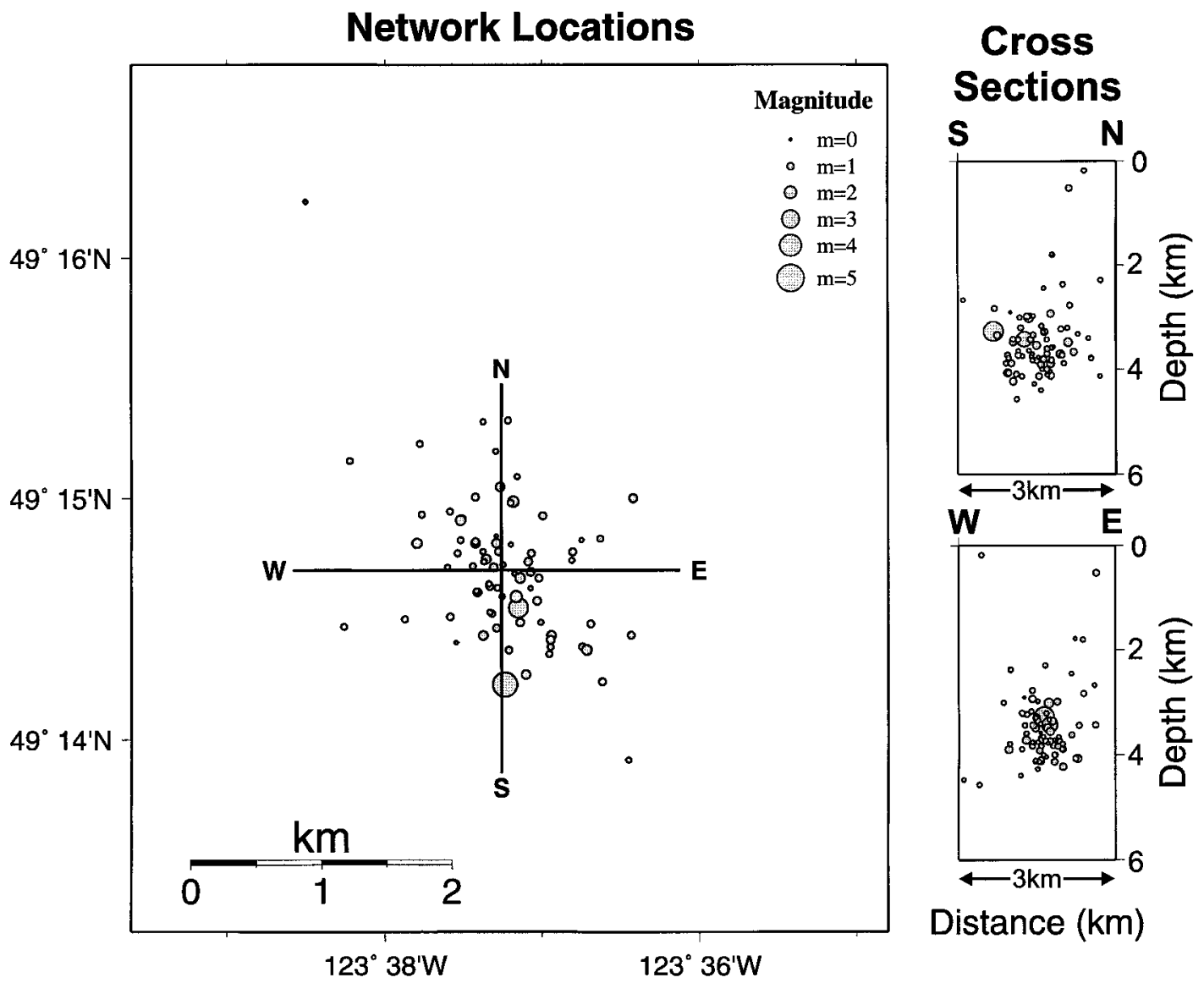

Figure 7. Standard network earthquake locations for the events considered in this study. Dot size is scaled to magnitude. Locations of the cross sections (right) are shown on the map. There is no obvious structure or rupture surface visible here. Horizontal and vertical errors $(1 \sigma)$ average $\pm 2.8 \mathrm{~km}$ and $\pm 6.9 \mathrm{~km}$, respectively. 
$\mathrm{Hz}$ ) seismograms were cross-correlated at stations within 28 $\mathrm{km}$ to $140 \mathrm{~km}$ from the cluster centroid. Two waveforms at a common station are considered similar when the correlation coefficient exceeds 0.8. The seismic stations used (see labelled stations in Figure 5) provide a good azimuthal coverage of the epicentral region. The similarity of the waveforms at each station (an example is shown in Figure 8) indicates that these earthquakes are nearly colocated and have similar focal mechanisms.

Of a total of 76 events that were initially considered, 55 events ranging in magnitude from $M_{\mathrm{L}} 0.3$ to 4.6 , had a sufficient number of arrivals (at least five phases) to be accurately relocated. The velocity model (Table 1) we use to solve the forward problem is based on the interpretation of seismic refraction data (Zelt et al., 1993; White and Clowes, 1984), seismic reflection data (including high-resolution studies that provide sediment thickness estimates (Mosher and Hamilton, 1998)), and earthquake studies (Mulder, 1995) conducted in the region.

The relocated hypocenters (Table 2) are shown in both map and cross-sectional view in Figure 9. Note that the epicenters fall within a 1.4-km-diameter area, and in crosssectional view there is a strong northward-dipping trend observed. The relative locations of these events are very well constrained, with average $2 \sigma$ standard errors of $\pm 110-120$ $\mathrm{m}$ horizontally, and $\pm 190 \mathrm{~m}$ vertically. As shown in Figure 10 , the north-dipping structure is particularly evident for the 24 largest earthquakes $(M>1)$ and is even clearer for the largest seven events in the sequence (all $M>1.5$ ). Here, a dip angle of $53^{\circ}$ is computed for the northward-dipping plane of aftershocks. The $2 \sigma$ errors in the vertical direction are indicated by bars for each event. Note that although the horizontal errors are not shown, they are small, approximately one-half those of the vertical. The dip angle resolved by the seismicity is in very good agreement with the dip angle of $47^{\circ}$ (dashed line in Figure 10) for the north-dipping plane in the mainshock focal mechanism solution.
Accuracy of Solutions and Error Estimates. The waveform cross-correlation and joint hypocentral determination method used in this study was developed and has been primarily used in regions of relatively dense seismograph station coverage. In the area considered here, the closest seismograph is $\sim 30 \mathrm{~km}$ from the epicenter, and the station spacing is approximately $30-50 \mathrm{~km}$. Thus, a valid question is how accurate are the relative hypocenters obtained from a sparse network? We have addressed this question by considering data from the dense Northern California Seismic Network and several well-recorded events along the northern Hayward Fault. These earthquakes were first located with Xadjust (Dodge, 1996) and the method outlined here, using all of the available data (e.g., 118 stations within $120 \mathrm{~km}$ of the epicenter, including 18 stations within $30 \mathrm{~km}$, and 3 stations within $10 \mathrm{~km}$ ), and then were relocated using various subsets of the data, including data distributions that closely resembled that available for the Strait of Georgia region (e.g., 13 stations within $120 \mathrm{~km}$ of the epicenter, with the closest stations at $28 \mathrm{~km}$ ). The results of this study (see Cassidy et al., 2000 for details), demonstrated that with the restricted data, the epicenters moved less than $150 \mathrm{~m}$, and still clearly resolved the orientation of the fault. Focal depths were more variable, typically changing by $500-700 \mathrm{~m}$, and in some cases by $1-1.5 \mathrm{~km}$. However, the vertical orientation of the fault was still clearly visible. Cassidy et al. (2000) conclude that even with a relatively sparse station coverage, and with the nearest stations at $30 \mathrm{~km}$, the relative locations are useful in delineating fault structure.

The $P$-wave velocity structure in the epicentral region is constrained by seismic refraction experiments, as described earlier. We have examined the potential effect of the earth model used on the hypocenter locations by allowing for reasonable changes to the starting earth model (e.g., removing the sediment layer, changing the thickness of the sedimentary package, moving the depth of the "high-velocity" layer from $8 \mathrm{~km}$, to $4 \mathrm{~km}$, to $12 \mathrm{~km}$ ), and varying Pois-
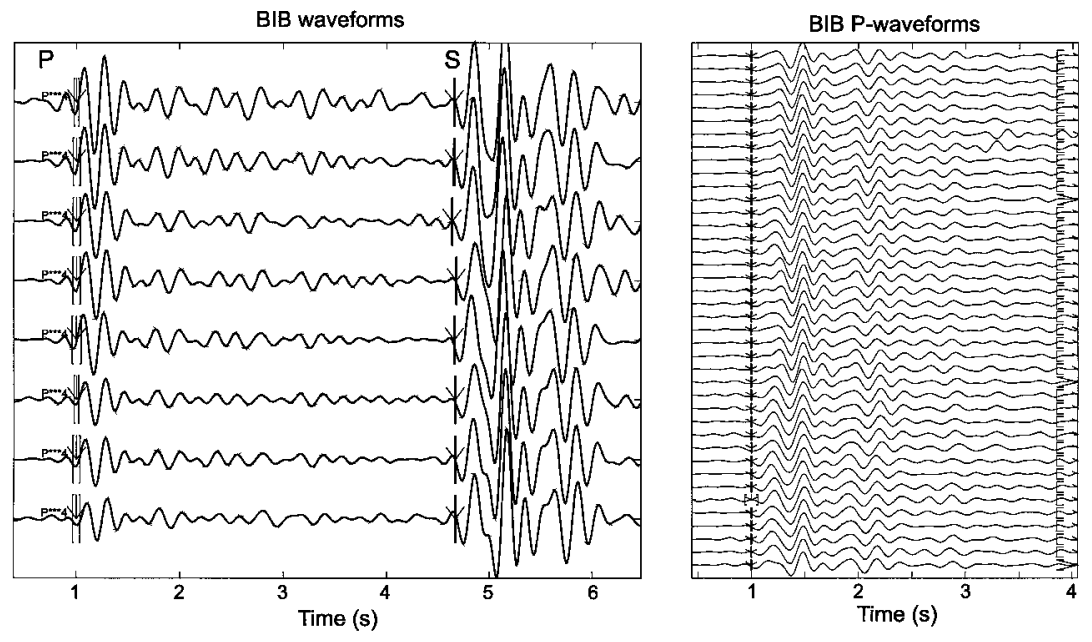

Figure 8. Vertical component waveforms recorded at seismic station BIB for a number of the events considered in this study. Both the $P$ waves and the $S$ waves (left) are similar, indicating that these events have similar mechanisms and are nearly colocated. A large number of the events have nearly identical waveforms (close-up of the $P$ waves is shown on the right). Seismograms are bandpass filtered from 2 to 8 $\mathrm{Hz}$. 
Table 1

Earth Model Used in the Relocation

\begin{tabular}{ccc}
\hline $\begin{array}{c}\text { Depth } \\
(\mathrm{km})\end{array}$ & $\begin{array}{c}V_{\mathrm{P}} \\
(\mathrm{km} / \mathrm{sec})\end{array}$ & $\begin{array}{c}V_{\mathrm{S}} \\
(\mathrm{km} / \mathrm{sec})\end{array}$ \\
\hline 0.0 & 1.2 & 0.6 \\
0.55 & 4.0 & 2.0 \\
2.0 & 6.2 & 3.53 \\
8.0 & 6.6 & 3.82 \\
22.0 & 7.0 & 4.05 \\
35.0 & 7.75 & 4.48 \\
\hline
\end{tabular}

son's ratio. The epicenters moved horizontally by up to about $300 \mathrm{~m}$, and depths changed by up to $1 \mathrm{~km}$; however, the earthquakes moved as a cluster so that their relative locations were not significantly dependent on the starting model. In all cases, the north-dipping band of hypocenters was found to be robust, as was the spatial extent of about $1.5 \mathrm{~km}$.

In addition to the mathematical relative uncertainties estimated from this analysis (average $2 \sigma$ standard errors of $\pm 110-120 \mathrm{~m}$ horizontally, and $\pm 190 \mathrm{~m}$ vertically), we have used a bootstrap method to examine the location uncertainties. Each event was relocated using numerous subsets of the complete arrival time data sets. In all cases, these bootstrap locations fell within the $2 \sigma$ standard errors estimated using the complete data sets.

\section{Stress Drop and Rupture Area}

A stress drop of 45 bars was estimated for the 24 June 1997 mainshock by Atkinson and Cassidy (2000) using the $S$-wave spectra at 22 regional sites. This value is higher than the average stress drop of about 30 bars observed in the area (Atkinson, 1995; Wahlström, 1993; Dewberry and Crosson, 1995) but well within the range of typical values observed for moderate-sized earthquakes in the Pacific Northwest (Dewberry and Crosson, 1996).

The seismic moment estimate for the 24 June 1997 earthquake is $3.17 \times 10^{15} \mathrm{~N} \mathrm{~m}$, based on body-wave and surface-wave amplitudes in the CMT solution (Malone et al., 1997). The stress drop and seismic moment estimates based on Brune's relation (Brune 1970, 1971) yields a circular rupture area of a $1.35-\mathrm{km}$ diameter. This is in good agreement with the relocated aftershocks (Fig. 9), which fall within a circular area of a $1.3-\mathrm{km}$ diameter on the surface (and corresponds to a circular area of a $1.8-\mathrm{km}$ diameter on a fault plane dipping at $53^{\circ}$ ). Thus, the relocated aftershocks define a region that is consistent with the estimated stress drop and seismic moment. As described subsequently almost all of the early aftershocks (within 24 hours of the mainshock) occurred about $650 \mathrm{~m}$ downdip and to the north of the mainshock location. These early aftershocks likely outline the northern limit of the ruptured segment.

Temporal Distribution. The relocated events in this earthquake sequence exhibit an interesting temporal sequence. It
Table 2

Events Analyzed in this Study

\begin{tabular}{|c|c|c|c|c|c|c|}
\hline \multirow{2}{*}{$\begin{array}{c}\text { Date } \\
\text { yyyymmdd }\end{array}$} & \multicolumn{2}{|c|}{ Time } & \multirow{2}{*}{$\begin{array}{l}\text { Lat. } \dagger \\
\left({ }^{\circ} \mathrm{N}\right)\end{array}$} & \multirow{2}{*}{$\begin{array}{l}\text { Lon. } \dagger \\
\left({ }^{\circ} \mathrm{W}\right)\end{array}$} & \multirow{2}{*}{$\begin{array}{l}\text { Depth } \dagger \\
(\mathrm{km})\end{array}$} & \multirow{2}{*}{$\begin{array}{l}\text { Mag. } \\
\left(M_{\mathrm{L}}\right)\end{array}$} \\
\hline & & SS.SS & & & & \\
\hline 19970613 & 1344 & 8.52 & 49.2393 & -123.6220 & 2.01 & $3.4 *$ \\
\hline 19970614 & 0127 & 53.32 & 49.2425 & -123.6230 & 3.10 & 0.7 \\
\hline 19970614 & 0934 & 0.74 & 49.2410 & -123.6231 & 2.61 & 0.3 \\
\hline 19970614 & 1328 & 7.93 & 49.2428 & -123.6260 & 2.78 & 0.7 \\
\hline 19970616 & 0127 & 56.40 & 49.2421 & -123.6244 & 2.74 & 0.7 \\
\hline 19970624 & 1440 & 30.48 & 49.2428 & -123.6266 & 2.65 & 4.6* \\
\hline 19970624 & 1445 & 20.38 & 49.2411 & -123.6220 & 2.90 & 1.4 \\
\hline 19970624 & 1508 & 43.77 & 49.2475 & -123.6288 & 2.57 & 0.7 \\
\hline 19970624 & 1547 & 0.04 & 49.2478 & -123.6271 & 3.31 & 0.8 \\
\hline 19970624 & 1832 & 17.49 & 49.2483 & -123.6288 & 3.02 & 0.9 \\
\hline 19970624 & 1904 & 16.77 & 49.2470 & -123.6241 & 2.77 & 1.2 \\
\hline 19970624 & 2006 & 37.38 & 49.2408 & -123.6184 & 2.34 & 1.2 \\
\hline 19970624 & 2020 & 29.46 & 49.2490 & -123.6234 & 3.02 & 1.1 \\
\hline 19970624 & 2103 & 25.43 & 49.2496 & -123.6226 & 3.30 & 1.0 \\
\hline 19970625 & 0254 & 23.78 & 49.2468 & -123.6255 & 2.82 & 1.2 \\
\hline 19970625 & 0308 & 17.27 & 49.2465 & -123.6248 & 2.80 & 1.0 \\
\hline 19970625 & 0330 & 9.09 & 49.2476 & -123.6301 & 3.05 & 0.7 \\
\hline 19970625 & 0351 & 15.13 & 49.2473 & -123.6298 & 2.85 & 1.2 \\
\hline 19970625 & 0503 & 37.79 & 49.2480 & -123.6230 & 2.94 & 0.9 \\
\hline 19970625 & 0536 & 57.85 & 49.2418 & -123.6270 & 2.93 & 0.7 \\
\hline 19970625 & 05412 & 26.31 & 49.2471 & -123.6286 & 2.96 & 1.1 \\
\hline 19970625 & 0605 & 29.10 & 49.2473 & -123.6291 & 2.84 & 0.7 \\
\hline 19970625 & 07212 & 28.49 & 49.2473 & -123.6298 & 2.85 & 0.9 \\
\hline 19970625 & 0905 & 12.92 & 49.2476 & -123.6286 & 2.87 & 1.0 \\
\hline 19970625 & 1002 & 25.10 & 49.2481 & -123.6226 & 3.14 & $1.7 *$ \\
\hline 19970625 & 1027 & 22.08 & 49.2471 & -123.6301 & 2.87 & 1.2 \\
\hline 19970625 & 1410 & 25.22 & 49.2453 & -123.6311 & 2.88 & 1.4 \\
\hline 19970626 & 0704 & 46.32 & 49.2478 & -123.6233 & 2.75 & 0.7 \\
\hline 19970627 & 0455 & 59.07 & 49.2415 & -123.6193 & 2.53 & $1.5^{*}$ \\
\hline 19970701 & 1113 & 10.37 & 49.2415 & -123.6308 & 1.99 & 0.5 \\
\hline 19970703 & 1105 & 26.62 & 49.2423 & -123.6195 & 2.82 & 0.2 \\
\hline 19970706 & 0757 & 10.51 & 49.2426 & -123.6286 & 2.91 & 0.6 \\
\hline 19970706 & 0759 & 1.97 & 49.2413 & -123.6331 & 1.97 & 0.7 \\
\hline 19970706 & 0808 & 8.16 & 49.2411 & -123.6323 & 1.96 & 0.5 \\
\hline 19970711 & 1036 & 7.22 & 49.2443 & -123.6293 & 3.66 & 0.7 \\
\hline 19970712 & 1844 & 48.63 & 49.2401 & -123.6285 & 3.08 & 0.9 \\
\hline 19970714 & 0405 & 49.51 & 49.2415 & -123.6323 & 3.13 & 0.9 \\
\hline 19970714 & 1117 & 4.31 & 49.2425 & -123.6195 & 2.73 & 1.1 \\
\hline 19970723 & 1957 & 18.17 & 49.2451 & -123.6256 & 2.86 & 0.7 \\
\hline 19970725 & 0127 & 22.80 & 49.2395 & -123.6258 & 2.24 & 0.7 \\
\hline 19970727 & 0331 & 30.10 & 49.2480 & -123.6225 & 3.65 & $1.6^{*}$ \\
\hline 19970727 & 1254 & 36.43 & 49.2423 & -123.6240 & 3.50 & 0.6 \\
\hline 19970801 & $2132 ?$ & 30.86 & 49.2458 & -123.6255 & 2.99 & 1.4 \\
\hline 19970801 & 2132 & 54.93 & 49.2465 & -123.6256 & 3.22 & 1.1 \\
\hline 19970819 & 0708 & 19.85 & 49.2455 & -123.6238 & 3.00 & 0.7 \\
\hline 19970819 & 0718 & 43.70 & 49.2453 & -123.6244 & 3.04 & 0.5 \\
\hline 19970823 & 1056 & 28.40 & 49.2465 & -123.6231 & 2.97 & 0.4 \\
\hline 19970823 & 1908 & 19.05 & 49.2473 & -123.6231 & 3.37 & 0.6 \\
\hline 19970823 & 1950 & 10.65 & 49.2473 & -123.6236 & 2.98 & 1.3 \\
\hline 19970824 & 0837 & 18.93 & 49.2460 & -123.6258 & 2.87 & 0.6 \\
\hline 19970824 & 0936 & 45.06 & 49.2476 & -123.6210 & 3.29 & 0.6 \\
\hline 19971111 & 1103 & 56.45 & 49.2421 & -123.6311 & 3.03 & 0.7 \\
\hline 19971226 & 0859 & 59.09 & 49.2461 & -123.6323 & 3.24 & $1.6^{*}$ \\
\hline 19971230 & 0617 & 2.82 & 49.2475 & -123.6226 & 2.80 & 1.0 \\
\hline 19980319 & 1634 & 26.23 & 49.2486 & -123.6213 & 3.40 & $1.8^{*}$ \\
\hline
\end{tabular}

*Denotes the largest $(M \geq 1.5)$ earthquakes; felt events are highlighted in bold.

$\dagger$ Latitude, longitude, and depth are relocations from this study. 
Final Locations

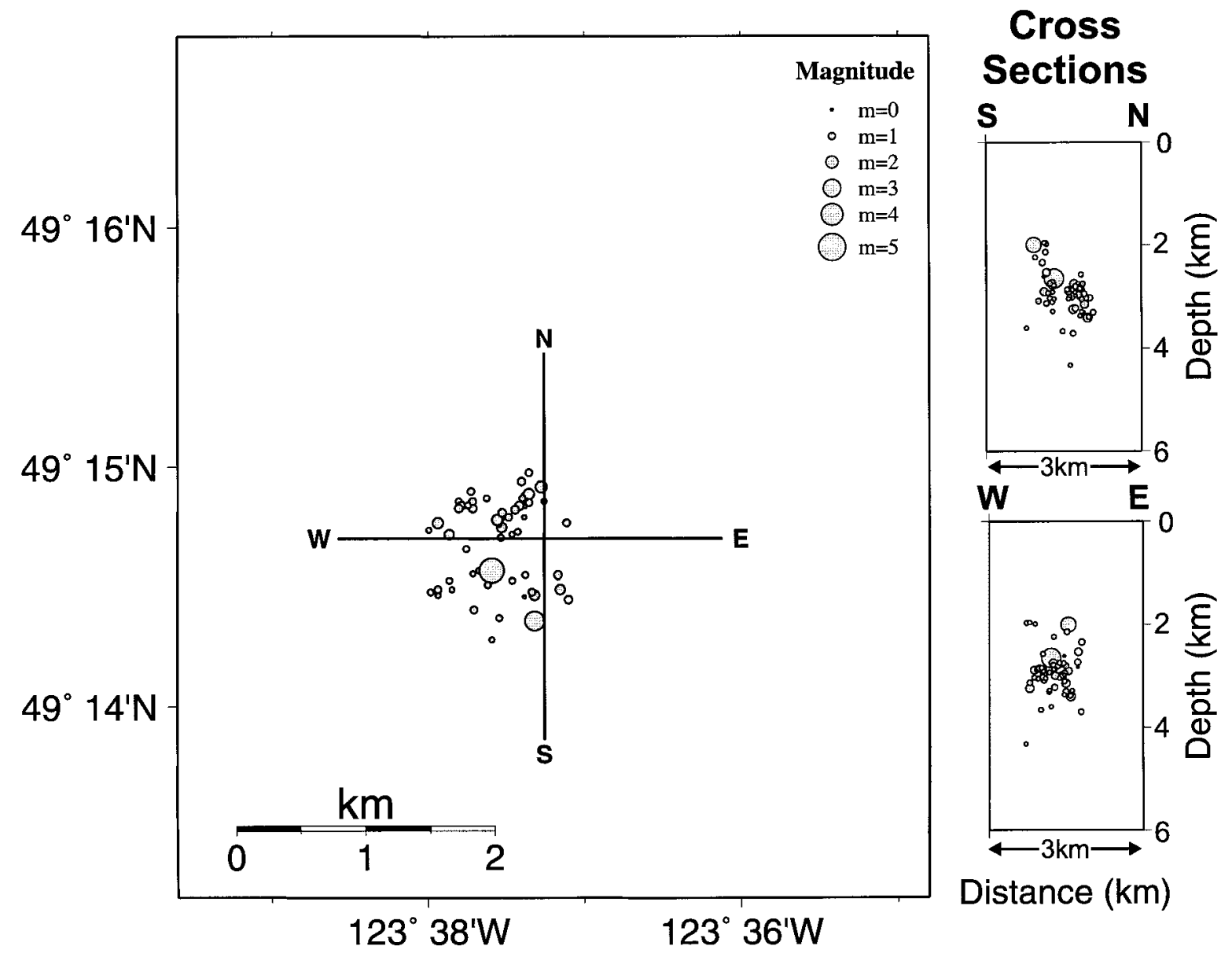

Figure 9. Relocated earthquake hypocenters. Dot size is scaled to magnitude. Locations of the cross sections (right) are shown on the map. In plan view, the epicenters are confined to a circular area of $1.3-\mathrm{km}$ diameter. In the north-south cross section, there is a strong north-dipping trend from 2 to $4 \mathrm{~km}$ depth.

is noteworthy that the 24 June 1997 mainshock is the first known significant earthquake in southwestern British Columbia known to be preceded by a felt foreshock. On 13 June 1997 a magnitude 3.4 earthquake occurred $0.5 \mathrm{~km}$ from the mainshock location and was felt throughout greater Vancouver and across southern Vancouver Island. This was the first shallow earthquake located at this site since 6 March 1997 (when a pair of shallow $M=0.6$ and 0.7 events occurred within four hours of one another), and the only significant event $(M>1)$ since 28 November 1995, when a shallow $M=2.8$ event occurred at this location. The 13 June 1997 event was followed by six very small events ( $M$ $=0.3-0.7$ ) prior to the 24 June 1997 mainshock. Of these, four were well-enough recorded to be relocated using the waveform cross-correlation technique. Note that these small events appear to migrate downdip and toward the site of the 24 June mainshock (Fig. 11). Although there are too few events to state definitively, there is some suggestion that the foreshock sequence occurred along a more steeply dipping plane (with an apparent dip of about $60-65^{\circ}$ as indicated by the dashed line with the question mark in Figure 11) than that of the mainshock sequence (Fig. 11). Within 24 hours of the mainshock, 23 small $(M=0.7-1.7)$ aftershocks were recorded. All but three of these were located downdip (Fig. 11 ), with most being concentrated in a small region about $650 \mathrm{~m}$ downdip and to the north of the mainshock location. These early aftershocks likely outline the northern limit of the ruptured segment of the north-dipping fault. In the month following the mainshock there were an additional 12 small events $(M=0.2-1.5)$ recorded. Most of these events are located within about $500 \mathrm{~m}$ of the mainshock location and at about the same focal depth.

\section{Discussion and Conclusions}

The 24 June $1997 M_{\mathrm{L}}=4.6$ earthquake, its foreshock, and aftershocks, represent the most accurately located shallow earthquake sequence near the populated centres of 


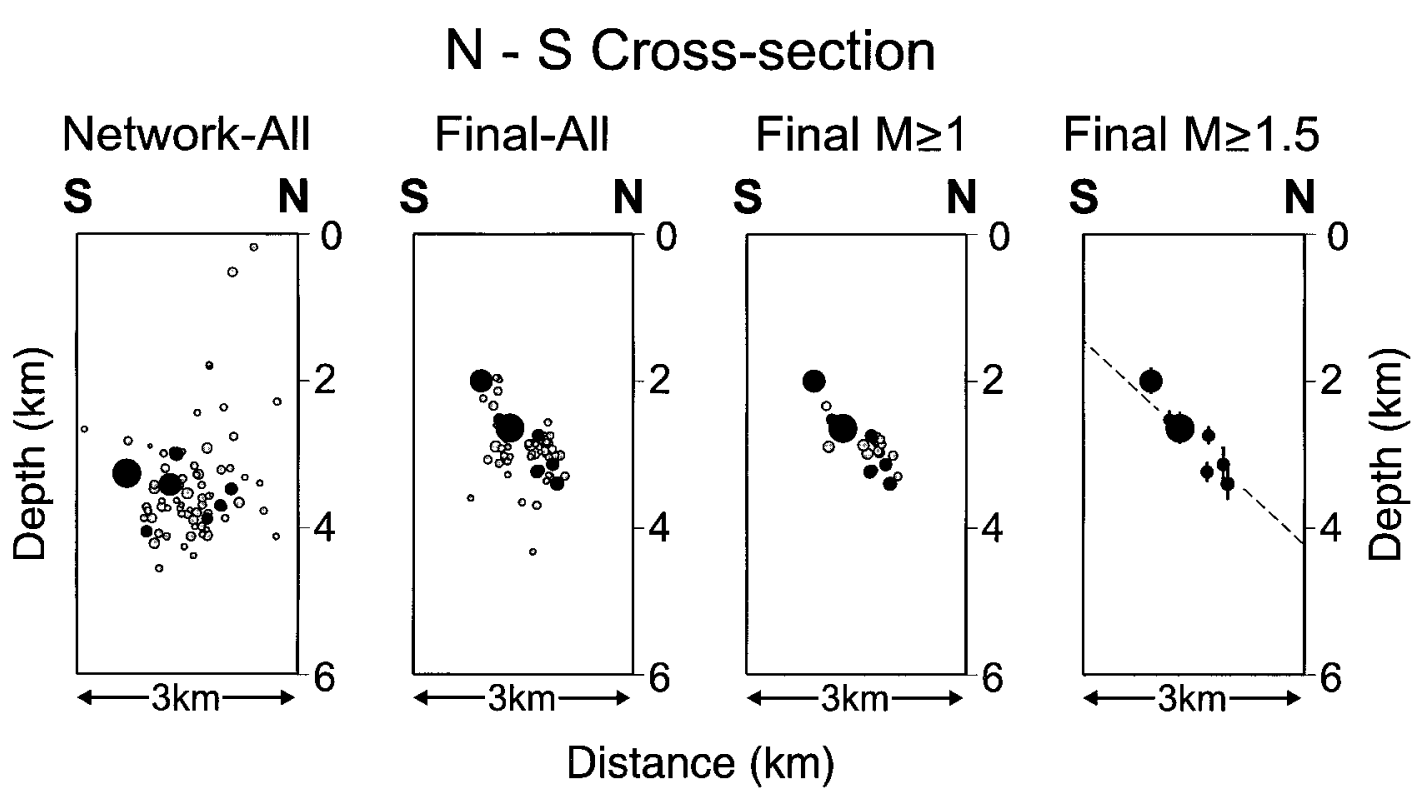

Figure 10. Earthquake hypocenters along a north-south cross section. Dot size is scaled to magnitude; the seven largest $\left(M_{\mathrm{L}} \geqq 1.5\right)$ events are highlighted with darker shading in each plot. From left to right: initial (network) locations; all relocated events; all events of $M_{\mathrm{L}} \geqq 1.0$, and the largest $\left(M_{\mathrm{L}} \geqq 1.5\right)$ events. In the latter plot, the vertical bars represent the $\pm 2 \sigma$ error bounds in focal depth, and the dashed line represents the dip angle of $47^{\circ}$ from the focal mechanism solution.

\section{Temporal Sequence}

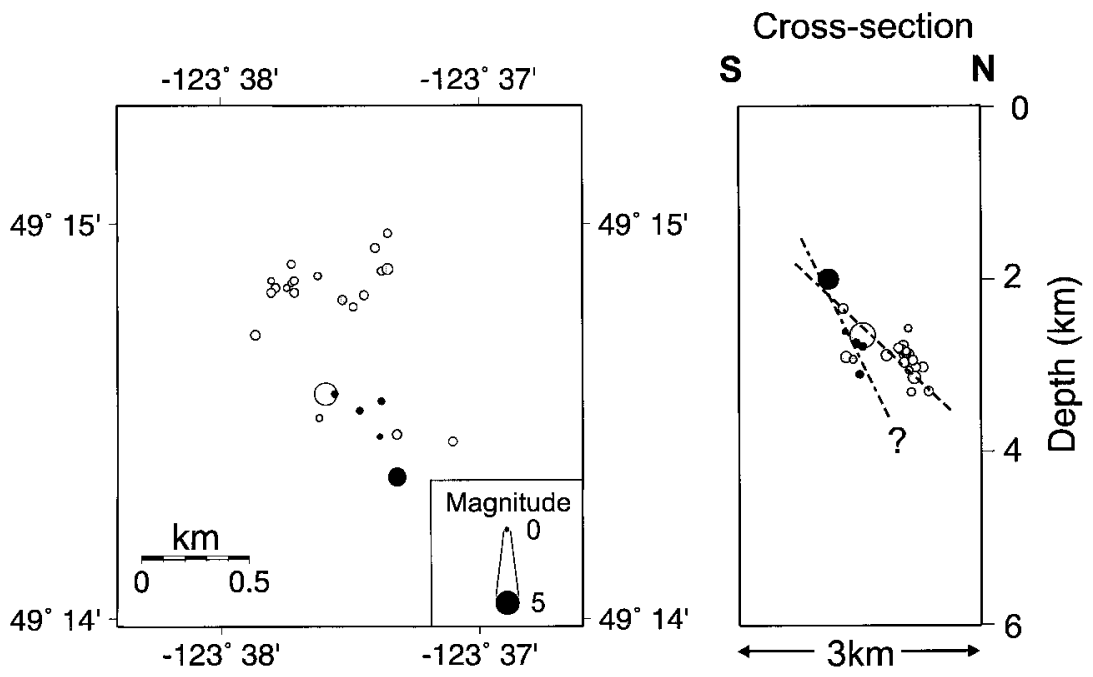

Figure 11. Temporal distribution of earthquake activity. The $M_{\mathrm{L}}=3.4$ foreshock of 13 June 1997 and its aftershock sequence are shown with darker fill, the 24 June $1997 M_{\mathrm{L}}=$ 4.6 mainshock, and aftershocks within the first 24 hours, are shown with lighter shading fill. Note that the foreshock is the shallowest event, seismic activity then migrates downward and toward the mainshock location about $500 \mathrm{~m}$ to the NNW. Almost all of the aftershock activity in the first 24 hours is clustered downdip, about 500-700 $\mathrm{m}$ to the north of the mainshock epicenter. Note that foreshock sequence may be along a more steeply dipping plane (indicated by a dashed line with a question mark) than that of the mainshock sequence (dashed line, no question mark), see text.

southwestern British Columbia recorded to date. These earthquakes occurred in a region of persistent shallow seismic activity beneath the Strait of Georgia, a basin with many similarities to the Puget Sound lowlands of Washington State.

The well-constrained focal mechanism for the 24 June 1997 mainshock shows thrust faulting along either a northdipping fault (strike $262^{\circ}$, dip $47^{\circ}$, slip $98^{\circ}$ ), or along a southdipping fault (strike $71^{\circ}$, dip $44^{\circ}$, slip $82^{\circ}$ ). A relocation of the earthquake hypocenters, using a waveform cross-correlation technique, clearly shows a north-dipping zone of hypocenters, with a dip angle of $53^{\circ}$, in good agreement with that estimated by the P-nodal solution. Thus, for the first time we have used earthquake focal mechanisms, and an alignment of accurately located hypocenters to characterize an active fault in southwestern British Columbia. The $M_{\mathrm{L}}=$ 3.4 foreshock (the only other event for which a focal mechanism could be computed) is not as well constrained and 
shows either predominantly thrust motion along a northnorthwest-dipping fault (strike $236^{\circ}$, dip $42^{\circ}$, slip $123^{\circ}$ ), which is rotated about $25^{\circ}$ relative to the mainshock fault plane, or predominantly strike-slip along a fault oriented in the same direction as the mainshock fault (strike $266^{\circ}$ ), but dipping more steeply with a dip angle of $72^{\circ}$. There is some support for a more steeply dipping plane for the foreshock sequence (relative to the mainshock and its aftershocks) from the precise relocations (Fig. 11).

The relocated hypocenters define a $1.3-\mathrm{km}$-diameter circular area. This is in good agreement with the expected rupture area (based on a Brune rupture model) for an earthquake of this size $\left(M_{0}=3.17 \times 10^{15} \mathrm{~N} \mathrm{~m}\right)$ and a stress drop of 45 bars. The temporal sequence of this earthquake sequence shows that the $M_{\mathrm{L}}=3.4$ foreshock was the shallowest event. Over the next 11 days, the earthquake activity migrated downdip and $400 \mathrm{~m}$ to the northwest, to the location of the mainshock epicenter. In the first 24 hours after the mainshock, almost all of the aftershock activity was located downdip and 500-700 $\mathrm{m}$ to the north of the mainshock epicenter.

The east-west orientation of the active north-dipping structure that we interpret beneath the Strait of Georgia is similar to the orientation of major thrust faults imaged recently in the Puget Sound area (Johnson et al., 1999a,b). The focal mechanism for the 24 June 1997 Georgia Strait event is similar to the mechanisms of recent moderate earthquakes in the Puget Sound area that may be associated with the Seattle Fault, including the $1995 M_{\mathrm{D}}=5$ Pt. Robinson earthquake (Dewberry and Crosson, 1996) and the $1997 M_{\mathrm{D}}$ $=4.9$ Bainsbridge Island earthquake (Weaver et al., 1999). Given the similar margin-parallel stress regime through the area, it is not surprising to see similar types of thrust structures and faulting. Preliminary analysis of the SHIPS seismic reflection data collected in the Strait of Georgia is providing the most detailed images, to date, of the structure in the epicentral area of these 1997 Georgia Strait earthquakes. Mosher et al. (2000) find that this earthquake sequence is located within a broad deformation zone in the marine environment where seismic reflectors show a loss of coherency, changing dip directions, and some offsets. A clear 8$\mathrm{km}$-long east-west trending aeromagnetic anomaly has been identified in the epicentral area (Mosher et al., 2000). The location and positive polarity of this anomaly is consistent with our interpreted sense of motion along the fault (south side down and north side up).

In summary, by combining earthquake focal mechanisms and precisely located hypocenters obtained from a waveform cross-correlation routine and joint hypocentral determination, we have characterized, for the first time, the orientation and sense of motion along an active fault in the vicinity of the urban centers of southwestern British Columbia.

\section{Acknowledgments}

We gratefully acknowledge Doug Dodge for providing his analysis program Xadjust and for his helpful advice, Claire Currie for her assistance in processing the waveform data, and Richard Franklin for his assistance in drafting many of the figures. We thank Bill Ellsworth, Porter Irwin, Maurice Lamontagne, Mark Molinari, and an anonymous reviewer for their thorough reviews and helpful comments. Most of these diagrams were generated using Generic Mapping Tools (Wessell and Smith, 1995). This is Geological Survey of Canada Contribution No. 2000043.

\section{References}

Atkinson, G. M. (1995). Attenuation and source parameters of earthquakes in the Cascadia region, Bull. Seism. Soc. Am. 85, 1327-1342.

Atkinson, G. M., and J. F. Cassidy (2000). Integrated use of seismograph and strong motion data to determine soil amplification: Response of the Fraser Delta to the Duvall, and Georgia Strait earthquakes, Bull. Seism. Soc. Am. 90, 1028-1040.

Baldwin, R. E. (1993). A simple algorithm for the rapid location of local and regional earthquakes (abstract), Geophys. Res. Lett. 64, 52.

Brune, J. N. (1970). Tectonic stress and the spectra of seismic shear waves from earthquakes, J. Geophys. Res. 75, 4997-5009.

Brune, J. N. (1971). Correction, J. Geophys. Res. 76, 5002.

Bucknam, R. C., E. Hemphill-Haley, and E. B. Leopold (1992). Abrupt uplift within the past 1700 years at southern Puget Sound, Washington, Science 258, 1611-1614.

Cassidy, J. F., and G. C. Rogers (1999). Seismic site response in the greater Vancouver, British Columbia, area: spectral ratios from moderate earthquakes, Can. Geotech. J. 36, 195-209.

Cassidy, J. F., G. C. Rogers, and D. H. Weichert (1997). Soil response on the Fraser Delta to the $\mathrm{M}_{\mathrm{w}}=5.1$ Duvall, Washington, earthquake, Bull. Seism. Soc. Am. 87, 1354-1361.

Cassidy, J. F., G. C. Rogers, D. H. Weichert, and T. E. Little (1998). Digital strong ground motion recordings of the June 1997, Strait of Georgia earthquake, Geol. Surv. Can. Open-File Rept. 3599, 39 pp.

Cassidy, J. F., G. C. Rogers, and F. Waldhauser, (2000). Precise relative hypocentres in a region of relatively sparse seismograph coverage? Some numerical tests, Geol. Surv. Can. Open-File Rept. (in preparation).

Dewberry, S. R., and R. S. Crosson (1995). Source scaling and moment estimation for the Pacific Northwest Seismograph Network using $S$ coda, Bull. Seism. Soc. Am. 85, 1309-1326.

Dewberry, S. R., and R. S. Crosson (1996). The $M_{D}=5.0$ Earthquake of 29 January 1995 in the Puget Lowland of Western Washington: an event on the Seattle Fault? Bull. Seism. Soc. Am. 86, 1167-1172.

Dodge, D. A. (1996). Micro-earthquake studies using cross correlationderived hypocenters, Ph. D. Thesis, Stanford University, Stanford, California, 146 pp.

Dodge, D. A., G. C. Beroza, and W. L. Ellsworth (1995). Evolution of the foreshock sequence of the 1992 Landers, California, earthquake and its implications for earthquake nucleation, J. Geophys. Res. 100, 9865-9880.

Dodge, D. A., G. C. Beroza, and W. L. Ellsworth (1996). Detailed observations of California foreshock sequences: implications for the earthquake nucleation process, J. Geophys. Res. 101, 22371-22392.

Ellsworth, W. L. (1977). Three-dimensional structure of the crust and mantle beneath the island of Hawaii, Ph. D. Thesis, Massachusetts Institute of Technology, Cambridge, Massachusetts, $327 \mathrm{pp}$.

England, T. D. J., and R. M. Bustin (1998). Architecture of the Georgia Basin southwestern British Columbia, Bull. Can. Petr. Geol. 46, 288320.

Fisher, M. A. et al. (1999). Seismic survey probes urban earthquake hazards in the Pacific Northwest, EOS Trans. 80, 13.

Frankel, A., C. Mueller, T. Barnhard, D. Perkins, E. V. Leyendecker, N. Dickman, S. Hanson, and M. Hopper (1996). National Seismic Hazard Maps, June 1996, Documentation, U.S. Geol. Surv. Open-File Rept. 96-532, 100 pp.

Johnson, S. Y., S. V. Dadisman, J. R. Childs, and W. D. Stanley, (1999a). Active tectonics of the Seattle fault and central Puget Sound, Wash- 
ington: implications for earthquake hazards, Bull. Geol. Soc. Am. 7, 1042-1053.

Johnson, S. Y., S. V. Dadisman, D. C. Mosher, R. J. Blakely, J. R. Childs, and S. B. Rhea (1999b). Neotectonics of the Devils Mountain Fault and Northern Whidbey Island Fault, Eastern Strait of Juan de Fuca and Northern Puget Lowland, Seism. Res. Lett. 70, 220 (abstract).

Ma, L., R. S. Crosson, and R. S. Ludwin (1991). Focal mechanisms of Western Washington earthquakes and their relationship to regional tectonic stress, U.S. Geol. Surv. Open-File Rept. 91-441-D.

Malone, S. D., R. S. Crosson, and A. I. Qamar (1997). Pacific Northwest seismograph network operations, 1997 Annual Report 1434-95-A1302, University of Washington, Seattle, Washington.

Monger, J. W. H. (1990). Georgia Basin: Regional setting and adjacent Coast Mountains geology, British Columbia, in Current Research, 1990-F, Geological Survey of Canada, 95-107.

Monger, J. W. H., and J. M. Journeay (1994). Basement geology and tectonic evolution of the Vancouver region, in Geology and Geological Hazards of the Vancouver Region, Southwestern British Columbia, J. W. H. Monger (Editor) Bulletin 481, Geological Survey of Canada, p. 3-25.

Mosher, D. C., and T. S. Hamilton (1998). Morphology, structure, and stratigraphy of the offshore Fraser delta and adjacent Strait of Georgia, in Geology and Natural Hazards of the Fraser River Delta, British Columbia, (Editors), J. J. Clague, J. L. Luternauer, and D. C. Mosher; Bulletin 525, Geological Survey of Canada, 147-160.

Mosher, D. C., J. F. Cassidy, C. Lowe, Y. Mi, R. D. Hyndman, and G. C. Rogers (2000). Neotectonics in the Strait of Georgia: First tentative correlation of seismicity with shallow geologic structure in southwestern British Columbia, in Current Research, 2000-A22, Geological Survey of Canada, 1-9.

Mulder, T. L. (1995). Small earthquakes in southwestern British Columbia, M.Sc. Thesis, University of Victoria, Victoria, British Columbia, $117 \mathrm{pp}$.

Muller, J. E. (1977). Evolution of the Pacific margin, Vancouver Island and adjacent regions, Can. J. Earth Sci. 14, 2062-2085.

Mustard, P. S., and G. E. Rouse (1994). Stratigraphy and evolution of Tertiary Georgia Basin and subjacent Upper Cretaceous sedimentary rocks, southwestern British Columbia and northwestern Washington State, in Geology and Geological Hazards of the Vancouver Region, Southwestern British Columbia, J. W. H. Monger (Editor), Bulletin 481, Geological Survey of Canada, p 97-169.

Pratt, T. L., S. Johnson, C. Potter, W. Stephenson, and C. Finn (1997). Seismic reflection images beneath Puget Sound, western Washington State: the Puget Lowland thrust sheet hypothesis, J. Geophys. Res. 102, 27,469-27,489.

Reasenberg, P. A., and D. Oppenheimer (1985). FPFIT, FPPLOT and
FPPAGE: Fortran computer programs for computing and displaying earthquake fault plane solutions, U.S. Geol. Surv. Open-File Rept. 85 739.

Roecker, S. W. (1981). Seismicity and tectonics of the Pamir-Hindu Kush region of central Asia, Ph. D. Thesis, Massachusetts Institute of Technology, Cambridge, Massachusetts, 294 pp.

Rogers, G. C. (1979). Earthquake fault plane solutions near Vancouver Island, Can. J. Earth Sci. 16, 523-531.

Rogers, G. C. (1998). Earthquakes and earthquake hazard in the Vancouver area, in Recent Geological, Geophysical, Geotechnical, and Geochemical Research, Fraser River Delta, British Columbia, J. J. Clague, J. C. Luternauer, and D. C. Mosher (Editors), Bulletin 525, Geological Survey of Canada, 19-25.

VanDecar, J. C., and R. S. Crosson (1990). Determination of teleseismic relative phase arrival times using multi-channel cross-correlation and least-squares, Bull. Seism. Soc. Am. 80, 150-169.

Wahlström, R. (1993). Comparison of dynamic source parameters for earthquakes in different tectonic regions of the northern Cascadia subduction zone, in Estimation of Earthquake Size, S. J. Duda and T. B. Yanovskaya (Editors), Tectonophysics 217 (spec. Sect.), 205-215.

Weaver, C. S., K. L. Meagher, A. Qamar, R. J. Blakely, and R. E. Wells (1999). The June 23, 1997 Bainsbridge Island, Washington, Earthquake: evidence that the Seattle Fault is seismically active, Seism. Res. Lett. 70, 219 (abstract).

Wessel, P., and W. H. F. Smith (1995). New version of the Generic Mapping Tools released, EOS Trans. Amer. Geophys. U. 76, 329.

White, D. J., and R. M. Clowes (1984). Seismic investigation of the Coast Plutonic Complex-Insular Belt boundary beneath the Strait of Georgia, Can. J. Earth Sci. 21, 1033-1049.

Zelt, B. C., R. M. Ellis, and R. M. Clowes (1993). Crustal velocity structure in the eastern Insular and southernmost Coast belts, Canadian Cordillera, Can. J. Earth Sci. 30, 1014-1027.

Geological Survey of Canada

Pacific Geoscience Centre

P.O. Box 6000

Sidney, British Columbia, Canada, V8L 4B2

cassidy@pgc.nrcan.gc.ca

(J. F. C., G. C. R.)

United States Geological Survey

345 Middlefield Road

Menlo Park, California 94025

(F. W.)

Manuscript received 16 March 2000. 